Anna Bendrat

DOI: 10.33896/PorJ.2021.10.2

(Uniwersytet Marii Curie-Skłodowskiej, Lublin,

e-mail: anna.bendrat@mail.umcs.pl)

ORCID: 0000-0002-5677-0296

Agnieszka Budzyńska-Daca

(Uniwersytet Warszawski,

e-mail: a.budzynska@uw.edu.pl)

ORCID: 0000-0003-1002-7197

Agnieszka Kampka

(Szkoła Główna Gospodarstwa Wiejskiego, Warszawa,

e-mail: agnieszka_kampka@sggw.edu.pl)

ORCID: 0000-0002-9732-6482

Ewa Modrzejewska

(Uniwersytet Warszawski,

e-mail: e.modrzejewska@uw.edu.pl)

ORCID: 0000-0003-0913-7540

Maria Załęska

(Uniwersytet Warszawski,

e-mail: m.zaleska@uw.edu.pl)

ORCID: 0000-0003-2973-0173

\title{
RETORYKA W POLSCE PO 1989 ROKU. PRZEGLĄD KIERUNKÓW BADAŃ
}

\section{WPROWADZENIE}

Poniższy przegląd kierunków rozwoju retoryki w ciagu ostatnich 30 lat w Polsce przedstawia proces samoorganizowania się obszaru badań, mającego ambicję stać się pełnoprawną dyscypliną. Po 1989 roku, w nowych warunkach polityczno-społecznych, zaczał wyłaniać się nowy obszar badawczy jako reakcja adaptacyjna na zmianę okoliczności historycznych. Zastosowana w artykule metodologia jest $z$ konieczności opisowa. Pierwszą część stanowi zarysowanie tła historycznego i podstawowych kierunków badań, a także sposobów ich wykorzystania do kształtowania polityki komunikacyjnej. W części drugiej pokazano tworzenie się stanu chwiejnej równowagi między badaniami retorycznymi i językoznawczymi, wraz $z$ rozmaitymi koncepcjami adaptacji wzorców perswazji do nowych warunków komunikacyjnych. W części trzeciej ukazano relację współzależności między studiami retorycznymi i medioznawczymi. Tematem części czwartej jest kształtowanie się studiów retorycznych w obszarze polityki, z perspektywy opisowej i aplikacyjnej. Część piąta poświęcona jest edu- 
kacji retorycznej w Polsce i działalności propagujacej rozwój dyscypliny. Uwzględnienie tych nakładających się perspektyw umożliwia zwrócenie uwagi na relacje intertekstualności w środowisku badaczy retoryki, a także na sposób wyodrębniania się indywidualnych ścieżek badawczych.

Celem artykułu nie jest prezentacja bibliografii z zakresu polskiej retoryki - takie prace były już publikowane [Lichański 1991; 2018] - ale wskazanie głównych kierunków badań i obszarów powinowactw między retoryka a innymi dyscyplinami w ciagu ostatnich trzydziestu lat.

Demokratyczne przemiany, które rozpoczęły się w Polsce po 1989 roku: wolność słowa, rozwój mediów, gospodarka wolnorynkowa, konkurencja na rynku idei i przekonań, przyczyniły się do powstania nowego typu podmiotu retorycznego - swobodnie wypowiadającego się obywatela, mającego poczucie rzeczywistego uczestnictwa w życiu społecznym. Procesy te uruchomily myślenie o retoryce $\mathrm{w}$ wymiarze praktycznym jako sztuce publicznego mówienia, którego warto (się) uczyć. Rozwój mediów, włączenie się w nurty globalizacji spowodowały przyspieszoną naukę nowych gatunków w przestrzeni komunikacyjnej, pozostających wcześniej w zawieszeniu. Znamiennym przykładem jest rozkwit nieznanej wcześniej debaty. Dość powiedzieć, że gatunek ten był na tyle słabo rozpoznawany w Polsce do lat 90. XX wieku, że w internetowym Słowniku języka polskiego, a więc kompendium semantycznym pojęć polskiej przestrzeni komunikacyjnej, debata do dziś jeszcze definiowana jest jako „poważna i długa dyskusja na ważny temat” [https://sjp.pwn.pl/sjp/debata;2554300.html]. Sens ten został utrwalony w społecznej świadomości na skutek braku tradycyjnych praktyk debatowania, czyli, najogólniej rzecz ujmując, prezentacji odmiennych poglądów spierajacych się stron w celu pozyskania audytorium [Budzyńska-Daca 2013; 2015]. W zamian za to dla obco (dla systemu niedemokratycznego) brzmiącego pojęcia <debata> ukształtowała się nowa konceptualizacja w postaci: „długich i poważnych dyskusji”. Ożywienie gatunków, uśpionych w okresie braku swobód obywatelskich, wolnej konkurencji idei, szło w parze $z$ kształtowaniem się nowych dyskursów. Wraz z rozwojem swobodnej komunikacji społecznej i wolnych mediów możliwe były praktyki interakcyjne wcześniej nieznane. Nowa sytuacja wymagała odpowiednich narzędzi opisu i analizy.

\section{KIERUNKI BADAŃ}

Tworzenie retorycznego warsztatu naukowego na gruncie polskim było przygotowywane już wcześniej przez badaczy zajmujących się literatura i kultura epok dawnych, przede wszystkim przez filologów klasycznych, m.in. Erazma Rykaczewskiego, Henryka Podbielskiego, Mieczysława 
Brożka, Mariana Wesołego, a później także Bartosza Awianowicza, Karolinę Ekes, Stanisława Śnieżewskiego, którym zawdzięczamy tłumaczenia najważniejszych dzieł retorycznych, m.in. progymnasmatów greckich, dzieł Arystotelesa, Hermogenesa, Cycerona, Kwintyliana. Krytyczne wydania tych dzieł stanowia cenny wkład filologiczny w zrozumienie pierwotnego znaczenia retorycznych terminów i kształtowanie polskiego metajęzyka dyscypliny. Badania nad polską retoryką średniowieczna, humanistyczna, barokowa, oświeceniowa, dziewiętnastowieczna były podejmowane przez historyków literatury od ponad stu lat. W zakresie badań literaturoznawczych i filologicznych cezura 1989 roku niewiele zmieniła. Nadana została tym badaniom nowa dynamika. Ukształtował się profil o charakterze aplikacyjnym $z$ wyraźnie zaznaczona potrzebą $z$ jednej strony rekonstrukcji i aktualizacji systemu starożytnej retoryki, a $z$ drugiej - włączenia badań zagranicznych do polskiego dyskursu naukowego.

Rzut oka na współczesną literaturę poświęcona retoryce pozwala wyodrębnić ważna grupę publikacji, fundamentalną dla rozwoju dyscypliny, która sa prace o charakterze słownikowym: Mirosława Korolki Sztuka retoryki. Przewodnik encyklopedyczny [1990] i przekład autorstwa Alberta Gorzkowskiego Retoryki literackiej H. Lausberga [2002], terminologiczny słownik teorii argumentacji [Szymanek 2001]. Zaliczają się do tej grupy także kompendia historycznoretoryczne i teoretycznoretoryczne niezbędne dla poznania ogólnej kultury retorycznej i przygotowania teoretyczno-metodologicznego, np. synteza retoryki opisowej opracowana przez Jerzego Ziomka [2000], historia retoryki przygotowana przez Jakuba Z. Lichańskiego [1992; 2000; 2003; 2007], tłumaczenie Wprowadzenia do retoryki Greków i Rzymian R.E. Volkmana [1995], słownik pojęć retorycznych dla prawników [Rybiński, Zeidler 2010]. Prace te maja między innymi tę zaletę, że porządkują terminologię właściwą dyscyplinie i cały system relacji semantycznych między nimi. $Z$ myślą o dydaktyce uniwersyteckiej prowadzonej na różnych wydziałach powstały podręczniki retoryki klasycznej [Jaroszyński, Jaroszyński 1998; Lichański 2007], ujmujące wielodyscyplinarne koligacje retoryki [Barłowska, Budzyńska-Daca, Wilczek 2008], podręczniki z ćwiczeniami [Barłowska, Budzyńska-Daca, Załęska 2011; Szymanek, Wieczorek, Wójcik 2003], podręczniki dla dziennikarzy [Pisarek 2002; Bogołębska, Worsowicz 2016], kaznodziejów [Korolko 2010], kompendia dla prawników [Korolko 2001; Jabłońska-Bonca 2002; Jabłońska-Bonca, Zeidler 2016]. Dla studentów i uczestników szkoleń warsztatowych $z$ negocjacji pomocny może być podręcznik zawierający materiały do przeprowadzania symulacji interakcji negocjacyjnych, który powstał we współpracy ze studentami specjalizacji medialnej na Wydziale Polonistyki Uniwersytetu Warszawskiego [Budzyńska-Daca, Modrzejewska 2018]. Wreszcie istotna pomoca dydaktyczną dla nauczycieli szkół średnich są odpowiednio przystosowane do poziomu wiedzy uczniów podręczniki retoryki jako kultury mówienia [Zgółka, Zgółka 2001; Karaś, Wierzbicka-Piotrowska 2002]. 
Rozprzestrzenienie się idei retorycznego kształcenia, zarówno do celów publicznej komunikacji, jak i do celów myślenia krytycznego, wiąże się $z$ popularyzacja retoryki. Potrzeba przełożenia klasycznych systemowych relacji na fragmenty, które można stosować do zrozumienia i tworzenia aktualnych przekazów publicznych, determinowała powstanie szeregu prac popularyzatorskich o charakterze podręcznikowym. Książki te sa skierowane do szerokiego grona odbiorców, zainteresowanych nie tylko doskonaleniem umiejętności praktycznych, lecz także retoryka jako elementem kultury komunikacji [Rusinek, Załazińska 2005; 2010].

Rozpoczęte w latach osiemdziesiątych dzieło tłumaczenia na język polski literatury obcej jest dziełem in statu nascendi daleko niepełnym. Jedno $z$ ważniejszych polskich pism literaturoznawczych „Pamiętnik Literacki” zamieszczało przekłady tekstów K. Burke’a, T. Todorova, A. Moss, B. Emricha, P. Zumthora, R. Douglasa, które później trafiły do antologii artykułów Retoryka opublikowanej przez M. Skwarę [2008]. Również książki monograficzne o starożytnych autorach, problemach lub szkołach zawieraja wiele przetłumaczonych fragmentów [Cichocka 1993; 1994; 2004; Mielczarski 2010]. Biblioteka retoryki została wzbogacona o teksty ważne dla rozwoju dyscypliny, m.in. prace K. Burke'a, Ch. Perelmana, P. De Mana, W. Bootha, S. Fisha, M. Meyera, J. Derridy. Ich pojawienie się wpłynęło zarówno na metody badań stosowane w obszarze literaturoznawstwa, jak i na formowanie się współczesnej retoryki.

Wyzwania nowej rzeczywistości społeczno-politycznej początku lat 90. XX w. spowodowały, że badania literaturoznawców uległy intensyfikacji, a nadto wyraziste stały się nowe kierunki badań nad retoryka, między innymi w obszarze komunikacji i dziennikarstwa, nauk o kulturze i religii, nauk o sztuce, socjologii, filozofii i prawa. Tradycyjnie identyfikowany jest strumień badań poświęconych tekstom staropolskim, od średniowiecza do XIX wieku. Sa to analizy retorycznych aspektów produkcji literackiej i naukowej lub innych pisemnych świadectw komunikacji wykształconych warstw społecznych. Jako przykład można przytoczyć monografie dotyczące retorycznej działalności polskich elit społecznych i intelektualnych [Barłowska 2000; 2010; Gorzkowski 2004; Budzyńska-Daca 2005; Skwara 2010; Partyka 2012; 2014; Trębska 2014; Ciszewska 2016; Czerenkiewicz 2019], retoryczne badania poezji staropolskiej [Hanczakowski, Niedźwiedź 2003; Krzywy 2014] lub specyfiki kulturowej piśmiennictwa regionalnego [Gaj 2003; 2007], w tym badanie i współczesna edycja traktatów retorycznych [Niebelska-Rajca 2012; Ryczek 2016; Chalecki 2009].

Badania poświęcone współczesnej retoryce są liczniejsze. Wiele prac eksploruje związek między retoryka a poetyka, zwłaszcza problem języka figuratywnego [Dobrzyńska 1994; Rusinek 2012]. Kolejnym obszarem badań jest teoria argumentacji. Wśród publikacji możemy wymienić ważne opracowania W. Marciszewskiego [1991] i W. Suchonia [2001] na temat logiki z punktu widzenia retoryki [Suchoń 2001], badania na 
temat argumentacji i perswazji [Tokarz 2006; Szymanek 2008; Wieczorek 2013; Warchala 2019; Budzyńska i in. 2014] lub na temat związków retoryki, sofistyki, erystyki [Lewiński 2012]. Problem stosowania argumentów i błędów argumentacyjnych w sytuacjach spornych został omówiony w publikacjach poświęconych komunikacji erystycznej [Kochan 2005; Budzyńska-Daca, Kwosek 2009]. Bardzo duża grupa publikacji znajduje się na pograniczu retoryki i analizy dyskursu [Molek-Kozakowska 2010; 2010a; 2011]. Retorykę - dyscyplinę i analizę dyskursu łączy zainteresowanie tym samym obszarem badań: $z$ jednej strony kontekstualizacja indywidualnego aktu komunikacyjnego, a $z$ drugiej jego konwencjonalizacja w gatunkach dyskursywnych. Podczas gdy analiza dyskursu bada cały akt komunikacyjny, analizy retoryczne uprzywilejowuja poszukiwanie tego, co może być przekonujące w danych okolicznościach. Wszystkie badania, mniej lub bardziej jednoznacznie, wskazuja na główną kwestię komunikacji: zróżnicowanie gatunków i rodzajów dyskursu.

Studia teoretyczne sprzyjaja refleksji nad epistemologia dyscypliny, konstrukcja perswazyjnych modeli komunikacji, formułowaniem kategorii analitycznych i opisowych, analiza i interpretacja istniejacych systemów pojęciowych. W badaniach głównie teoretycznych poruszane sa zagadnienia dotyczace statusu retoryki wobec filozofii [Mielczarski 2011; 2017], omawiany jest zwiazek między retoryka a retorycznością [Rusinek 2003]; badania nad Nowa Retoryką Perelmana [Kleszcz 2005; Kiereś-Łach 2015], zwiazek retoryki z innymi dyscyplinami badawczymi [Załęska 2012; 2014; 2015; 2021], filozoficzne i etyczne źródła retoryki [Rzymowska 2013; Gondek 2018; Gondek 2020] lub konceptualizacja retoryki wizualnej [Rusinek 2012; Kampka 2011; Sarna, Sęk-Iwanek 2016], studia nad retoryka liczb [Modrzejewska 2019], retoryka feminizmu [Pawlak-Hejno 2016], retoryka powieści kryminalnej [Ryszkiewicz 2021], retoryka Internetu i gier komputerowych. Wymienione zagadnienia znajduja się wśród tematów artykułów zamieszczanych w kwartalnikach „Forum Artis Rhetoricae” i „Res Rhetorica”.

\section{WPEYW BADAŃ AMERYKAŃSKICH NA ROZWÓJ POLSKIEJ RETORYKI}

W ciagu ponadtrzydziestoletniej historii polskich badań retorycznych znaczacy wpływ na ich rozwój miała amerykańska krytyka retoryczna. Jej początki sięgają lat dwudziestych ubiegłego stulecia [Jaroszyńska 1988; Bendrat 2016a]. Współcześnie jest reprezentowana przez kilka nurtów metodologicznych: klasyczny, socjologiczny, dramaturgiczny, genologiczny, ideologiczny, genderowy, metaforyczny [Foss 2017; Jost, Olmsted 2012].

Warto zaznaczyć, że tradycja starożytnej retoryki w Stanach Zjednoczonych była traktowana przede wszystkim jako motywacja w dziedzinie 
życia obywatelskiego i pożądany wzór praktyk politycznych. Stany Zjednoczone chciały być postrzegane jako nowy typ państwa, który rozwija się, sięgając do najcenniejszych idei politycznych starożytnego świata. Tymczasem w Europie, a więc także w Polsce, dziedzictwo retorycznej starożytności było często postrzegane jako tradycja myślenia o tym, co właściwe, a co niewłaściwe. Innymi słowy, traktowano retorykę w przeważającej mierze jako narzędzie utrzymania hierarchicznego porządku społecznego, a więc także jako instrument gwarantujący przywileje elitom społeczno-politycznym (co było szczególnie ważne w dobie rzeczpospolitej szlacheckiej). Wydaje się, że w polskim i amerykańskim systemie edukacyjnym do dziś widać odległe echa powyższych tendencji. W polskiej szkole - jeśli chodzi o kształcenie umiejętności komunikacyjnych - nadal można zaobserwować bardzo duży nacisk na umiejętność naśladowania wzorca. Ogromne znaczenie maja kwestie wierności tradycji i włączenia kultury polskiej w paneuropejska przestrzeń kulturowa. W Stanach Zjednoczonych natomiast większy nacisk kładzie się na kreatywność uczniów, na inspirowanie ich do znalezienia odpowiedzi na pytanie, kim chca być i jak powinni się zachować w obecnej sytuacji. W tym kontekście mniejszy nacisk kładzie się na ćwiczenie właściwej / niewłaściwej komunikacji, więcej czasu zaś poświęca się rozwijaniu kompetencji oddzielania informacji przydatnych od bezużytecznych, ponieważ informacje maja potencjał wywoływania obywatelskiej transformacji.

Spośród przedstawicieli amerykańskiej krytyki retorycznej szczególne miejsce w polskich badaniach zajmuje dorobek Kennetha Burke'a [18971993], który stał się w ostatnim trzydziestoleciu źródłem odniesienia i inspiracji dla polskich badaczy różnych dyscyplin [Wasilewski, Nita 2012; Bendrat 2012]. Wszechstronny charakter spojrzenia K. Burke'a na retorykę i naturę ludzka znajduje szerokie zastosowanie w dziedzinie nauk o języku i mediach [Sobczak 2018], antropologii [Mokrzan 2010; 2016], politologii [Hordecki 2017; 2018] i kulturoznawstwa [Bendrat 2013; 2019a]. To, co autorzy uważają za szczególnie istotne, to dramatystyczne ramy krytyki retorycznej K. Burke'a, zwłaszcza koncepcja pentady [Wasilewski 2012; Szurek 2015; Bendrat 2019b; Rzepecka 2019] rozwinięta w Grammar of Motives [1945] i Rhetoric of Motives [1950]. Innym wkładem Kennetha Burke'a w teorię retoryczna, która znajduje odzwierciedlenie w polskich badaniach naukowych, jest koncepcja identyfikacji. Znalezienie wspólnej płaszczyzny porozumienia pozwala nam zbadać sposoby, w jakie możemy być wobec siebie wspólistotni, co jest warunkiem wstępnym przezwyciężenia lub zneutralizowania różnic w komunikacji. Wreszcie, $z$ perspektywy społeczno-kulturowej i antropologicznej zaleta, która polscy uczeni dostrzegaja w podejściu Kennetha Burke'a, jest to, że pozwala im ono na rozszerzenie zakresu stosowania retoryki poza dyskurs przywódców (np. retoryka prezydencka). Kompleksowa koncepcja retoryki K. Burke’a jako wyposażenia do życia (equipment for living) jest atrakcyjna metodologicznie, szczególnie w badaniach antropo- 
logicznych [por. Mokrzan 2010; 2019], dotyczacych oddolnych doświadczeń w obszarze tzw. wernakularnej retoryki.

Na szczególną uwagę zasługują badania polskich amerykanistów, poświęcone prezydentom amerykańskim. Można wyodrębnić wśród nich kilka nurtów: (a) analizę przemówień w duchu klasycznej lub ideologicznej krytyki [Rzepecka 2018b; Kuś 2016; 2020]; (b) systemowa analizę treści w rekonstruowaniu ewolucji konkretnego tematu, takiego jak retoryka kryzysu [Rzepecka 2018a], (c) połączenie perspektywy zarówno nauk politycznych, jak i nauk o komunikacji, aby zademonstrować potencjał interdyscyplinarny badań w odniesieniu do aktywności amerykańskich prezydentów [Bendrat 2016a]. Niestety, nie zaobserwowano bezpośredniej transpozycji amerykańskiego aparatu metodologicznego $\mathrm{w}$ analogicznych badaniach retoryki przywódców politycznych w Polsce. Dwoma najbardziej zasadnymi wyjaśnieniami tej sytuacji moga być niekompatybilność polskiego i amerykańskiego systemu politycznego parlamentaryzmu i prezydentury, a także ograniczona dostępność oryginalnych źródeł i brak ich polskich tłumaczeń.

Innym przykładem interdyscyplinarnego podejścia do badania amerykańskich historycznych tekstów kultury i języka figuratywnego są badania Michała Choińskiego [2016; 2020], które wykorzystują retoryczną koncepcję metatropów Haydena White'a [1978] i koncepcję hiperboli jako „retoryki nadmiaru” Christophera D. Johnsona [2010].

$\mathrm{Na}$ znaczeniu zyskuja prace $z$ zakresu krytyki retorycznej powstałe poza środowiskiem amerykanistów, eksplorujące metodologię wypracowana w badaniach amerykańskich [Andrychowski 2020 - inspiracja metoda Michaela C. McGee; Szurek 2019 - analizy komunikacji lokalnej metoda Ernesta Bormanna].

\section{PERSPEKTYWA JĘZYKOZNAWCZA}

Refleksja nad językiem nie musi dotyczyć retoryki, natomiast refleksja nad retoryką w sposób nieunikniony odwołuje się do języka [Załęska 2012]. Język, używany w rozmaitych formach gatunkowych, jest bowiem podstawowa materia retoryki.

Terminy język i retoryka czasem sa traktowane jako synonimy, zwłaszcza w publicystyce (mówi się np. o języku prawicy lub o retoryce prawicy). Czasami jednak leksem język jest uznawany za neutralny, retoryka natomiast ma konotacje negatywna: jest traktowana jako manipulacyjne używanie języka. Ze względu na konotację negatywną część autorów, wypowiadając się o kwestiach zasadniczo mieszczących się $\mathrm{w}$ ramach retoryki, zamiast terminu retoryka używa terminu język, co widać w tytułach publikacji. 


\subsection{Praktyki perswazyjne}

Po roku 1989 pojawiła się przestrzeń do kultywowania retoryki jako perswazji racjonalnej (przekonywanie społeczeństwa przez polityków do radykalnej zmiany ustroju i mentalności na bardziej liberalna, w etymologicznym sensie tego słowa, odwołującym się do pojęcia wolności). Szybko także wykształciły się rozpoznawalne wzorce komunikacji kapitalistycznej $-z$ centralnym pojęciem wolnego rynku, ideologia sukcesu indywidualnego, determinacja do dokonywania zmian i bogacenia się oraz charakterystyczna dla tej formacji dyskursywnej propagandą sukcesu indywidualnego i rozwiniętymi praktykami autoprezentacji.

$\mathrm{W}$ ostatnich latach, podobnie jak w innych krajach, w Polsce na sile zyskał dyskurs głoszący tezy antykapitalistyczne. Obok krytyki racjonalnej pojawiła się także krytyka populistyczna kapitalizmu i liberalizmu, obie o odmiennych założeniach retorycznych i innej agendzie politycznej.

W warunkach wolności wyboru i dobrowolnej współpracy zamiast przymusu kompetencje komunikacyjne zaczęto postrzegać jako jeden $z$ najważniejszych środków do uzyskania pożądanych celów: zmiany bezinteresownej (dla dobra wspólnego obywateli, pro publico bono) lub interesownej (dla indywidualnej kariery i sukcesu).

Wspomniane wyżej okoliczności polityczno-ekonomiczne wywołały ogromne zainteresowanie obywateli tzw. kompetencjami miękkimi: zarówno czynnymi (umiejętnościami używania języka perswazyjnego przez siebie samego), jak i receptywnymi (rozpoznawaniem sposobów używania języka perswazyjnego przez innych, aby nie dać się zwieść). Pojawiło się zainteresowanie praktycznymi poradami dotyczącymi podniesienia umiejętności komunikacyjnych.

W odpowiedzi na popyt pojawiła się podaż: od poziomu popkultury masowej do poziomu profesjonalnego doradztwa indywidualnego w zakresie sposobów komunikacji. Poczatkowo polegało to na tłumaczeniu książek i adaptacji na grunt polski różnych form edukacyjnych (np. warsztatów, debat), głównie $z$ rynku amerykańskiego. Potem zaczęły się pojawiać poradniki rodzimych autorów, uwzględniające specyfikę kulturowa Polski.

Bardziej elitarny jest poziom zawodowego doradztwa indywidualnego: powstało wiele zawodów związanych $z$ doskonaleniem perswazji (spin doctors, speech-writers, public relations specialists, marketing specialists, coaches), o różnym poziomie profesjonalizmu i etyki. Zapośredniczenie praktyk retorycznych poprzez profesjonalistów w używaniu języka i retoryki oznacza zwrócenie większej uwagi dla aspektu receptywnego. Kompetencją profesjonalistów mają być wysokie umiejętności przewidywania, jak zareaguje audytorium na dany przekaz perswazyjny i w zależności od tego jego odpowiednia konstrukcja. 


\subsection{Język i retoryka: badania wplywające na politykę?}

Podczas gdy obywatele sa zainteresowani praktycznymi umiejętnościami perswazyjnymi do natychmiastowego zastosowania, przedstawiciele nauk o języku koncentrują się na wglądzie teoretycznym, w miarę możliwości neutralnym, w kwestie języka i retoryki. Wprawdzie cel badań jest zasadniczo nieinstrumentalny (wiedza dla wiedzy: zrozumienie mechanizmów i wykrycie wzorców używania języka), ale coraz częściej formułuje się także cele instrumentalne: zdobywanie wiedzy o języku, która można wykorzystać do działania, kształtowania polityki i podejmowania decyzji: jak interweniować i/lub kształtować postępowanie w sposób kompetentny [zob. Załęska, Okulska 2016].

Przedstawiciele nauk o języku dbaja o własna samoświadomość dyscyplinarna, stąd studia nad relacjami między lingwistyką a retoryka w Polsce, czasem na tle porównawczym $z$ innymi krajami [Załęska 2005; 2006; 2008; Mamcarz-Plisiecki 2018; Stalmaszczyk, Cap 2014]. Powstaja badania nad zastosowaniami języka i retoryki w praktykach rozpowszechniania wiedzy: dziennikarskich, popularyzatorskich, dydaktycznych i naukowych [Załęska 2014; 2016].

Przedstawiciele nauk o języku staraja się też zwiększać świadomość aktualnych formacji dyskursywnych kapitalizmu i ich wpływu na postępowanie ludzi; zob. badanie uwzorowania języka i retoryki biznesu [Kochan 2016], języka sukcesu [Wolny-Peirs 2005], krytyczna analiza kolonizacji rozmaitych praktyk perswazyjnych przez język marketingu [Smoleń-Wawrzusiszyn 2018].

Wzrasta także zainteresowanie dyskursem poradniczym; zob. badania nad popkulturowymi poradnikami w dziedzinie komunikacji perswazyjnej [Załęska 2019] czy nad praktykami samodoskonalenia i samokontroli wypowiedzi, propagowanymi przez bardziej elitarny coaching [Mokrzan 2019].

Badaczy interesuja także alternatywne w stosunku do klasycznych źródła „tego, co może być przekonujące” [Arystoteles]. Przykładem może być wykorzystanie narracji - oryginalnie uznawanej za nieperswazyjna formę komunikacji - do celów perswazyjnych (pojęcie <storytelling> w polityce i marketingu). Innym źródłem „tego, co może być przekonujące", sa ślady cyfrowe, zostawiane przez użytkowników w ramach nieperswazyjnych form komunikacji. Ze śladów tych można pozyskać dane, służące do projektowania nowych form perswazji. Podstawowym wkładem lingwistów i badaczy retoryki nie jest zatem wpływ na język polityki i działania polityczne w sposób bezpośredni, lecz niebezpośredni, poprzez rozwijanie świadomości języka i retoryki. 


\section{RETORYKA A NAUKA O KOMUNIKOWANIU I MEDIACH}

Drugim istotnym filarem rozwoju badań i edukacji retorycznej sa studia nad mediami i komunikacja społeczna. Warto zaznaczyć, że retoryka jako przedmiot nauczania pojawiła się dość wcześnie w programach studiów dziennikarskich. W 1970 r. ukazała się książka pt. Retoryka dziennikarska autorstwa Walerego Pisarka (1931-2017), prekursora włączania perspektywy retorycznej do badań nad mediami. Ten podręcznik oraz jego zaktualizowana wersja, wzbogacona m.in. o rozważania na temat słowa i obrazu [Nowa retoryka dziennikarska 2002], były wielokrotnie wznawiane i do dziś stanowią elementarz w edukacji dziennikarskiej.

Warto dodać, że zwiąany z Krakowem badacz był twórca ówcześnie nowej dziedziny lingwistycznej - interdyscyplinarnego prasoznawstwa. Był też przez wiele lat redaktorem naczelnym kwartalnika naukowego „Zeszyty Prasoznawcze”, najstarszego polskiego czasopisma naukowego poświęconego aspektom komunikowania masowego, w tym retoryce dziennikarskiej.

Współczesna edukacja retoryczna na wydziałach dziennikarskich związana jest $z$ językiem $w$ mediach i ma charakter $w$ dużej mierze aplikacyjny. Przykładowo ministerialne rozporządzenie z 2007 r. [Dz.U. 2007 nr 164 poz. 1166] narzucało już obowiązkowe kształcenie w zakresie retoryki i erystyki, które obejmowało następujące zagadnienia:

- komunikowanie jako perswazja,

- językowe środki perswazyjne; percepcja i zrozumiałość przekazu medialnego,

- techniki przekonywania według retoryki klasycznej; współczesne techniki perswazyjne, chwyty retoryczne,

- kryteria poprawności językowej z punktu widzenia skuteczności oddziaływania,

- skuteczne wypowiadanie się w mowie i w piśmie; konstrukcja tekstu według zaleceń współczesnej retoryki,

- redagowanie tekstów własnych, oceny tekstów cudzych,

- sztuka dyskutowania, erystyka w praktyce,

- retoryka w polityce i w reklamie.

O ile ministerialne zagadnienia odnosily się zarówno do szerszej tematyki dotyczacej funkcjonowania perswazji, jak i do węższych praktycznych technik tworzenia tekstów perswazyjnych, o tyle wymagane efekty kształcenia skupiły się głównie wokół actio, tj.:

umiejętności i kompetencje przekonywania i dyskusji; przemawiania okolicznościowego; wygłaszania przemówień; zabierania głosu; rozwiazywania konfliktów; postępowania zgodnego ze strategia argumentacyjna i negocjacyjna; stosowania chwytów erystycznych; postępowania zgodnego ze strategia argumentacji emocjonalnej [Rozporzadzenie (...) z dnia 12 lipca 2007 r. w sprawie standardów kształcenia]. 
Jak widać, retorykę ograniczono zatem do roli repertuaru technik udoskonalających głównie sztukę wystapień publicznych.

Retoryka w nieodłącznej parze $z$ erystyką stały się też elementem specjalności, które były wymieniane przez grupę badaczy postulujących utworzenie w polskim systemie naukowo-akademickim oddzielnej dyscypliny naukowej, tj. nauk o mediach - na wzór podobnie funkcjonujacych w innych krajach Media Studies, Media Science, Communication Studies, Journalism Studies. Od 2011 r. nauki o komunikacji społecznej i mediach stały się oficjalną dyscypliną w obrębie nauk społecznych, w ramach której można uzyskać stopień naukowy.

Wśród wymienionych obszarów badawczych „nowej” dyscypliny znalazły się takie zagadnienia i metody, które $z$ powodzeniem wykorzystywane sa pod szyldem retoryki od lat, szczególnie w krajach zachodnich, m.in. badania wpływu mediów (rozumienie przekazów medialnych; framing), badania języka mediów i języka w mediach (ilościowa i jakościowa analiza zawartości mediów, analiza semiologiczna, ilościowe badania frekwencyjne, badanie formalnych aspektów komunikacji medialnej, metody kulturoznawcze i filologiczne, analiza retoryczna); komunikowanie polityczne (ilościowa i jakościowa analiza zawartości, wywiady, wywiady pogłębione, ankiety, badania porównawcze) itd. [Jabłonowski, Gackowski 2012].

Warto odnotować wydane w ostatniej dekadzie publikacje, w których włącza się perspektywę retoryczną do badań nad mediami: Retoryka telewizji Barbary Sobczak [2018], O „duchu stosowności” Moniki Worsowicz [2013], Retoryka reklamy Piotra H. Lewińskiego [1999].

Retoryka może też być elementem interdyscyplinarnych badań, jak w wypadku Opowieści o Polsce. Retoryka narracji Jacka Wasilewskiego [2012], gdzie opisane zostały retoryczne mechanizmy narracyjnych schematów w polskiej polityce, historii i mediach.

Stosunkowo nowym obszarem badań jest retoryka wizualna oraz cyfrowa. Zdaje się, że w kontekście badań nad mediami, w tym mediami społecznościowymi, należy wyjść poza tradycyjna dla klasycznej retoryki analizę tekstu na rzecz perspektywy multimodalnej, gdyż sam przekaz medialny przestaje być jednorodna (gatunkowo, stylistycznie, perswazyjnie), zamknięta struktura, a słowu najczęściej towarzyszy obraz (zdjęcie, grafika, infografika, interaktywny wykres, zwizualizowane dane, nagranie filmowe, animacja, mem itd.) oraz często dźwięk [Modrzejewska 2019].

\section{RETORYKA I BADANIA JĘZYKA POLITYKI}

Polską retorykę polityczną ukształtowało kilka czynników o charakterze społeczno-politycznym: świadomość historyczna, osobowości konkretnych polityków, którzy przez wiele lat obecni sa na scenie politycznej, rozwój mediów i nowe formy komunikacji politycznej oraz globalne zmiany kulturowe zwiazane ze stylem uprawiania polityki. W retoryce 
polskich polityków odnajdujemy watki i osie sporu obecne w polskiej myśli politycznej jeszcze w XIX wieku: romantyzm i pozytywizm. Obydwa nurty ukształtowały osobne wzory etosu polityka. $Z$ jednej strony miałby to być charyzmatyczny przywódca, prowadzący naród do walki o niepodległość, $z$ drugiej - zapobiegliwy, nieulegający nadmiernym emocjom, skuteczny dyplomata i efektywny gospodarz. Obydwa nurty można wciąż obserwować w polskim dyskursie politycznym [Kłosińska 2003; 2005].

Drugim historycznym punktem odniesienia jest okres po II wojnie światowej. Lata 1945-1989, kiedy w Polsce, znajdującej się w sferze wpływów Zwiazku Radzieckiego, dominowała komunistyczna propaganda. Jej polska odmiana nie wyróżniała się niczym szczególnym na tle innych [Głowiński 1991; 2009]. W latach 70. i 80. XX wieku w dyskursie publicznym pojawił się także głos opozycji politycznej, a jednym z jej postulatów było odkłamanie języka w przestrzeni publicznej. Peerelowska nowomowa była tylko jednym $z$ możliwych wzorów wykorzystania perswazji w języku [Pisarek 2007, 366], niewatpliwie jednak ówczesna propaganda bardzo silnie podważyła zaufanie do dyskursu publicznego. Obcowanie $z$ nowomową nie pozostało bez wpływu także na niektórych obecnych polityków. Przez lata na polskiej scenie politycznej dominowali ludzie, którzy dorastali przed 1989 rokiem: ich wzorce komunikacyjne ukształtowane zostały przez język poprzedniego systemu politycznego lub przez opozycję wobec tych wzorców. W sposobie mówienia niektórych polityków - co istotne, starszego i młodszego pokolenia - wciąż przejawiaja się wzorce typowe dla nowomowy: od bylejakości języka, pustosłowia, wielosłowia, dominacji stylu urzędowego, deformowania znaczeń, ogólnikowości, kiczu stylistycznego [Dubisz 1992, 157] do manipulacji.

Historia polskiej retoryki politycznej XX i XXI wieku to ścieżka, która przeszło wiele państw majacych za soba doświadczenia autorytarnych lub totalitarnych rządów. W polskiej polityce zachodziły rewolucyjne zmiany, które w dojrzałych demokracjach ewolucyjnie nadawały kształt współczesnym stylom komunikacji politycznej.

Badacze proponuja różne klasyfikacje dyskursów ideologicznych. Jerzy Bralczyk pisze o trzech wzorcach komunikacji politycznej: konserwatywnym (wybieranym przez ugrupowania konserwatywne i narodowe, o nastawieniu antykomunistycznym, chrześcijańskie, niepodległościowe), liberalnym (korzystają $z$ niego partie podkreślające wartość społeczeństwa obywatelskiego i demokracji parlamentarnej) i socjalistycznym [Bralczyk 2001, 99]. Kazimierz Ożóg natomiast wskazuje na typy dyskursu: romantyczny (związany z „Solidarnościa”, odwołujący się do wartości narodowych i chrześcijańskich), liberalny (odpowiadajacy podejściu ekonomicznemu, technokratycznemu) i populistyczny (najsilniej $z$ tych trzech typów nasycony emocjami [Ożóg 2004, 44-46]). Podział zaproponowany zaś przez Katarzynę Kłosińska oparty jest nie na kwestiach światopoglądowych, lecz językowych, autorka wyróżnia język misji i język interesów oraz dyskurs otwarty i zamknięty. Kryteria klasyfikacji 
w tym wypadku to rola, jaka przypisuje sobie nadawca i gotowość do porozumienia $z$ innymi aktorami sceny publicznej. W języku misji dominuje retoryka aksjologiczna, politycy przedstawiają siebie jako tych, którzy przywrócą właściwy porządek wartości w życiu publicznym, natomiast politycy posługujący się językiem interesów i retoryką pragmatyczną prezentuja się przede wszystkim jako fachowcy, którzy - po otrzymaniu od wyborców mandatu - rozwiążą konkretne problemy obywateli [Kłosińska 2005, 211; 2012].

Obecnie obserwować możemy skutki kolejnego przełomu, tym razem technologiczno-społecznego; chodzi o retorykę polityczną funkcjonująca w kontekście nowych mediów. Naprzemienność ról nadawcy i odbiorcy, nowe kwestie polityczne, nowe ruchy polityczne (np. tzw. ruchy miejskie, aktywiści skupiajaccy się wokół konkretnych spraw danej społeczności lokalnej), nowe środki komunikacji i towarzyszace im nowe środki wyrazu (np. memy) tworzą nową sytuację retoryczną. Dodać do tego należy także zmianę pokoleniowa: politycy, którzy przez ostatnie 25 lat grali pierwsze skrzypce w polskiej polityce, zaczynają ustępować miejsca ludziom młodszym. Trudne do uchwycenia sa na razie zmiany zachodzace w polskiej retoryce politycznej pod wpływem członkostwa w UE (sa one bardziej wyraziste w dyskursie biurokratycznym niż politycznym). Rosnące znaczenie komunikacji wizualnej, skrótowość i fragmentaryczność przekazu, który dociera do odbiorców - wszystko to buduje nowy kontekst, w którym działa współczesny polityk [Kampka 2009; 2014a].

W polskich badaniach nad językiem polityki wyróżnić można kilka nurtów metodologicznych i kilka najczęściej podejmowanych zagadnień. Duża grupę stanowia prace analizujące nowomowę, teksty propagandy komunistycznej, a w ostatnich latach także powrót tych nawyków komunikacyjnych w wypowiedziach polityków i dziennikarzy [Głowiński 1991; Bralczyk 2003; Rusinek, Kłosińska 2019]. Zmiany zachodzace w języku polityki tuż przed rokiem 1989 i po roku 1989 stały się przedmiotem licznych publikacji, będących przeważnie zbiorami artykułów rejestrujących na bieżąco nowe zjawiska i formy językowe: badacze różnych dyscyplin starali się uchwycić moment przełomu, zmiany w dyskursie politycznym [Kamińska-Szmaj 2001; 2007]. Obecnie wśród prac poświęconych językowi polskiej polityki żywo rozwija się nurt analizy dyskursu [Czyżewski, Kowalski, Piotrowski 1997; Czyżewski, Kowalski, Tabako 2010], marketingu i komunikacji politycznej oraz publikacje $z$ pogranicza kilku dyscyplin naukowych: językoznawstwa, politologii, dziennikarstwa [Wasilewski 2006]. Język polityki analizowany jest pod kątem skuteczności, agresywności, manipulacyjności lub perswazyjności [Mosiołek-Kłosińska, Zgółka 2003; Sobczak, Zgółkowa 2007]. Badane sa także nowe formy wypowiedzi politycznej, zwiąane $z$ rozwojem Internetu, jak chociażby blogi. Analizy gramatycznych, syntaktycznych czy stylistycznych środków wykorzystywanych przez politycznych liderów są domena językoznawców. W naukach politycznych ważne miejsce zajmuje natomiast 
opis stylu przywództwa, sposobu budowania tożsamości partyjnej, różnych wymiarów kultury politycznej.

Prace dotyczące języka polityki pokazują, jak różnorodne sytuacje komunikacyjne można analizować i interpretować przy wykorzystaniu aparatu retorycznego [Załęska 2012a; Bendrat 2016b; Kampka 2012; Budzyńska-Daca 2012a; 2012b; 2015; 2016]. Badacze analizuja wykorzystanie poszczególnych środków retorycznych (np. metafor), argumentacje stosowana w politycznych sporach, typ przywództwa [Załęska 2012b; Kampka 2013a, 2013b]. Przedmiotem badań lingwistów, ale także medioznawców, antropologów, kulturoznawców, socjologów czy historyków sięgających po narzędzia retoryczne, jest dyskurs parlamentarny, komunikacja polityczna w nowych mediach czy wreszcie polityczny dyskurs medialny. Analizuje się np. metafory, które tworza ramy poznawcze (teatr, wojna, sport) [Kampka 2013a; 2013b], uatrakcyjnianie języka ze względu na wymogi medialne [Bralczyk, Wasilewski 2007], sposoby prowadzenia i relacjonowania sporu [Modrzejewska 2012; 2013; 2014; Budzyńska-Daca 2012b; 2015]. W ostatnich latach coraz częściej przedmiotem analizy retorycznej staje się nie tylko język polityki, ale także szeroko rozumiana komunikacja wizualna.

Retoryka badana jest jako narzędzie zdobywania i sprawowania władzy, zarówno w wymiarze parlamentarnym, jak i w kontekście ruchów społecznych oraz społecznych protestów. Ogromny dział zajmuja prace dotyczace demokracji deliberatywnej, jej teoretycznych założeń i codziennych praktyk, relacje retoryki i władzy w kontekście komunikacji internetowej, problemy zaangażowania obywatelskiego lub jego braku. Retoryka pojawia się bardzo często w kontekście analiz dotyczących wielkich zmian społecznych, polityki międzynarodowej [Załęska 2012b; Kampka 2012].

\section{RETORYKA I KSZTALCENIE UNIWERSYTECKIE}

Złożenie: retoryka i edukacja ma wymiar specyficzny, bo odnosi się do nauczania retoryki jako wiedzy zarówno teoretycznej (rhetorica docens), jak i praktycznej (rhetorica utens), a także retoryki jako nośnika wiedzy, który ma wpływ na rozwój i prezentację na rynku idei przekazów właściwych wymienionym wyżej dziedzinom. Problem retorycznej edukacji w Polsce był tematem konferencji naukowych, których pokłosiem sa tomy Uwieść słowem, czyli retoryka stosowana [Lichański 2003] i Dydaktyka retoryki [Sobczak, Zgółkowa 2011]. Tematy, które w tej dyskusji się pojawiły, to: podkreślenie wagi tradycji takiego kształcenia od zarania demokracji do XIX wieku (retoryka jako ars artium, regina artis scientaeque), edukacja retoryczna $\mathrm{w}$ innych obszarach kulturowych w porównaniu $z$ uwarunkowaniami polskimi (skąd czerpać wzorce edukacyjne dla naszego systemu nauczania), efektywność metod kształcenia w zależno- 
ści od poziomu szkoły (analiza podstawy programowej i realizacja treści retorycznych w podręcznikach po reformie edukacji z 1999 r.) i wreszcie retoryka na różnych kierunkach studiów (kształcenie retoryczne w poszczególnych dyscyplinach wiedzy).

Edukacja retoryczna w Polsce odbywa się w kilku obszarach. Po pierwsze, na uniwersytetach, w połączeniu $z$ badaniami naukowymi; po drugie w szkołach na poziomie podstawowym i średnim; po trzecie w obszarze edukacji komercyjnej, organizowanej przez firmy szkoleniowe i coachingowe; po czwarte - w obszarze organizacji pozarządowych i w praktykach samokształceniowych.

Najsilniejsze centra rozwoju retoryki to wydziały największych polskich uniwersytetów. Dopiero w latach 90 . XX wieku pojawiły się pierwsze kursy retoryki na wydziałach humanistycznych i społecznych polskich uczelni. Dostrzeżono potrzebę kształcenia retorycznego na studiach filologicznych, dziennikarskich, prawniczych, komunikologicznych. Retoryka rzadziej jest samoistnym przedmiotem nauczania, zwykle występuje w dyscyplinarnych klastrach w zależności od wydziału czy specjalizacji: np. retoryka dziennikarska, retoryka i erystyka, retoryka w komunikowaniu publicznym, retoryka i PR. Powodzeniem ciesza się kursy poświęcone retoryce użytkowej (np. retoryka praktyczna, retoryka wystąpień publicznych, emisja głosu) eksplorujące głównie elementy actio. Ważnym nurtem w edukacji akademickiej jest nurt metodologiczny: retoryka $\mathrm{w}$ badaniach literackich, analiza retoryczna, krytyka retoryczna.

Gdyby spojrzeć na mapę instytucjonalnego kształcenia w zakresie retoryki, ważne miejsce należy przyznać kształceniu podyplomowemu. Pierwsze studia podyplomowe powstały w 1995 roku na Uniwersytecie Jagiellońskim. Kształca się tam absolwenci wielu polskich uczelni, chcący usprawnić swój warsztat komunikacyjny. Podobną rangę mają cykliczne kursy retoryki w Instytucie Badan Literackich Polskiej Akademii Nauk. Podyplomowe kursy organizowane sa na wielu wydziałach polskich uniwersytetów mniej lub bardziej systematycznie. Pierwsze studia licencjackie i magisterskie $z$ zakresu retoryki powołane zostały na Wydziale Filozoficznym Katolickiego Uniwersytetu Lubelskiego.

W ciagu przeszło trzydziestu lat rozwoju polska retoryka uzyskała samoświadomość dyscypliny naukowej. Nie jest to jeszcze status, który znalazłby potwierdzenie $\mathrm{w}$ formalnych zapisach ministerialnych, ale głęboko odczuwany przez badaczy, którzy prowadza tu badania interdyscyplinarne lub badania w swoich dyscyplinach, korzystając $z$ retorycznego instrumentarium. 


\section{DZIALALNOŚĆ POLSKIEGO TOWARZYSTWA RETORYCZNEGO I INNE INICJATYWY NAUKOWE}

Duży wkład w rozwój dyscypliny i popularyzacji kształcenia retorycznego w Polsce wniosło Polskie Towarzystwo Retoryczne [Załęska 2013]. Jego członkowie reprezentują różne dyscypliny (m.in.: literaturoznawstwo, filologię klasyczna, neofilologie, językoznawstwo, historię, filozofię, socjologię). Sa wśród nich zarówno doświadczeni badacze, jak i początkujacy pracownicy nauki.

Polskie Towarzystwo Retoryczne powstało w 2000 roku z inicjatywy J.Z. Lichańskiego i zainicjowało wydawanie czasopisma naukowego „Forum Artis Rhetoricae”. Celem Towarzystwa jest propagowanie badań z zakresu retoryki, ale także budowanie właściwego rozumienia retoryki w odbiorze społecznym. Służą temu konferencje naukowe, seminaria, warsztaty i wieloraka działalność publikacyjna.

Polskie Towarzystwo Retoryczne współpracuje $z$ zagranicznymi ośrodkami i instytucjami, między innymi z Rhetoric Society of Europe. Organizuje konferencje krajowe i międzynarodowe $z$ udziałem specjalistów $z$ innych krajów europejskich. W 2015 roku odbyła się na Uniwersytecie Warszawskim konferencja „Rhetoric in the Knowledge Society”, która zgromadziła ponad stu badaczy z Europy i Stanów Zjednoczonych. Jej owocem były dwa tomy studiów Rhetoric, discourse and knowledge [Załęska, Okulska 2016] i Rhetoric, knowledge and the public sphere [Kampka, Molek-Kozakowska 2016]. Ważna inicjatywa sa Międzynarodowe Warsztaty Krytyki Retorycznej na Wydziale Nauk Humanistycznych Uniwersytetu Marii Curie-Skłodowskiej w Lublinie [2019 i 2021 r.], towarzyszące konferencji „Media w Ameryce, Ameryka w mediach”.

Polskie Towarzystwo Retoryczne prowadzi też szeroka działalność wydawniczą. Obecnie jest wydawcą międzynarodowego kwartalnika „Res Rhetorica", w którym publikuja, w języku polskim i angielskim, badacze $z$ Polski i z zagranicy. Ponadto prowadzi serię naukowa Rhetoricum poświęcona monografiom tematycznym. Organizuje też seminaria metodologiczne oraz warsztaty dotyczace technik prowadzenia debat. Patronuje ponadto wielu wydarzeniom promujacym idee rozwoju retoryki, m.in. konkursom krasomówczym, konferencjom i warsztatom z zakresu komunikacji społecznej. Organizuje także doroczny konkurs na najlepszą pracę dyplomową $z$ retoryki.

Działalność konferencyjna prowadzą także inne uniwersytety. Cykliczne konferencje retoryczne organizowane sa na Wydziale Filologii Polskiej i Klasycznej Uniwersytetu Adama Mickiewicza w Poznaniu i Katolickim Uniwersytecie Lubelskim, a także, mniej regularnie, na tych uniwersytetach, na których prowadzone są badania interdyscyplinarne o profilu retorycznym. Owocem konferencji sa monografie wieloautorskie, poświęcone istotnym tematom społecznym i kulturowym, np. związkom cielesności i retoryki [Cieślak 2008], codzienności retoryki [Marcjanik 
2006], dydaktyce retoryki [Sobczak, Zgółkowa 2011], perspektywom polskiej retoryki [Sobczak, Zgółkowa 2007], etyce i retoryce [Sobczak, Zgółkowa 2009], powinowactwom retoryki [Sobczak 2017], zwiąkom retoryki i demokracji [Mielczarski 2017a], zagadnieniom aksjologicznym [Budzyńska-Daca, Modrzejewska 2019], wizerunkowi medialnemu [Budzyńska-Daca, Kampka, Molek-Kozakowska 2016], komunikacji specjalistycznej [Załęska 2015], retorycznym normom komunikacji [Partyka 2017], retoryce wizualnej [Kampka 2014b].

\section{ZAKOŃCZENIE}

Od początku istnienia retoryki praktyka poprzedzała teorię. Przedstawiony w niniejszym artykule proces tworzenia intelektualnej i instytucjonalnej przestrzeni dla studiów retorycznych w Polsce potwierdza tę prawidłowość. Wolny rynek, pluralizm polityczny, różnorodność publicznych i prywatnych mediów, które pojawiły się w Polsce po upadku poprzedniego ustroju realnego socjalizmu, wiąały się $z$ ponownym pojawieniem się wielu praktyk retorycznych zabronionych lub zapomnianych w kraju po II wojnie światowej, a rozwijanych organicznie w państwach demokratycznych. Reklama i marketing, debaty polityczne, spory światopoglądowe, aktywność społeczna wymagały od obywateli nowych umiejętności perswazyjnych, skutkiem tego było zaś pojawienie się oferty edukacyjnej. Były to podręczniki i poradniki, początkowo głównie tłumaczenia prac amerykańskich i niemieckich, $z$ czasem publikacje rodzimych autorów; kursy i szkolenia adresowane do różnych grup społecznych; elementy retoryczne w kształceniu szkolnym i akademickim.

Nowe formy komunikacji perswazyjnej stały się polem zainteresowania dla badaczy. W polskich pracach dotyczacych retoryki wskazać możemy trzy źródła wiedzy i inspiracji teoretycznej. Po pierwsze, jest to tradycja dawnego oratorstwa szlacheckiego. Choć formy i treści staropolskich mów okolicznościowych i politycznych oraz staropolskich autorów podręczników retorycznych są odległe od współczesnego kontekstu, to prace filologów zajmujacych się literatura dawna przyczyniły się do utrwalania wiedzy na temat instrumentarium retorycznego. Po drugie, badania dotyczace peerelowskiej nowomowy, języka totalitarnej propagandy wielokrotnie służą jako punkt odniesienia, dostarczając pojęć i klasyfikacji. Paradoksalnie pomagaja także rozpoznawać i nazywać perswazyjne zabiegi stosowane we współczesnych zideologizowanych dyskursach publicznych. Trzecim źródłem sa koncepcje retoryczne rozwijane w innych krajach, które poprzez kontakty naukowe i tłumaczenia kluczowych prac $z$ zakresu argumentacji, krytyki retorycznej, badań nad mediami, analizy dyskursu stanowia zaplecze rozwoju rodzimej dyscypliny. 


\section{Bibliografia}

K. Andrychowski, 2020, "Ideografy” w polskich realiach? Krytyka ideograficzna Michaela Calvina McGee w polskiej perspektywie badawczej, „Res Rhetorica” 7(3), s. 185-202.

M. Barłowska, 2000, Jerzy Ossoliński-orator polskiego baroku, Katowice.

M. Barłowska, 2010, Swada i milczenie. Zbiory oratorskie XVII-XVIII wieku-prolegomena filologiczne, Katowice.

M. Barłowska, A. Budzyńska-Daca, P. Wilczek (red.), 2008, Retoryka, Warszawa.

M. Barłowska, A. Budzyńska-Daca, M. Załęska (red.), 2010, Ćwiczenia z retoryki, Warszawa.

A. Bendrat, 2012, Jak usankcjonować despotyzm w demokratycznym kraju? Analiza retorycznej strategii Lincolna w świetle teorii Kennetha Burke'a [w:] A. Kampka (red.), Między znaczeniem a działaniem. Retoryka i władza, Warszawa, s. 51-62.

A. Bendrat, 2013, President Goes to Hollywood: Popular Culture Depictions of the White House World [w:] E. Just, M. Wojtaszek (red.), Esthetic Experiments: Interdisciplinary Challenges in American Studies, Newcastle upon Tyne, s. $105-122$.

A. Bendrat, 2016a, Mowa jest złotem. Amerykański prezydent i retoryka, Warszawa.

A. Bendrat, 2016b, Medialne portrety imigrantów a hiperrzeczywistość obrazu [w:] A. Budzyńska-Daca, A. Kampka, K. Molek-Kozakowska (red.), Retoryka wizerunku medialnego, Warszawa, s. 197-224.

A. Bendrat, 2019a, Wartość wielokulturowości $w$ dialogu społecznym a kreacja etosu w sieci [w:] A. Budzyńska-Daca, E. Modrzejewska (red.), Retoryka i wartości, Warszawa, s. 126-144.

A. Bendrat, 2019b, Rhetoric in Digital Communication: Merging Tradition with Modernity, „Res Rhetorica” 6(3), s. 111-124.

B. Bogołębska, M. Worsowicz, 2016, Retoryka i jej zastosowania, Łódź.

J. Bralczyk, 2001, O języku polskiej propagandy politycznej lat siedemdziesiatych, Warszawa.

J. Bralczyk, 2003, O języku polskiej polityki lat osiemdziesiatych i dziewięćdziesiatych, Warszawa.

J. Bralczyk, J. Wasilewski, 2007, Polityka $w$ retoryce, retoryka $w$ polityce. Analiza dyskursu parlamentarnego [w:] B. Sobczak, H. Zgółkowa (red.), Perspektywy polskiej retoryki, Poznań, s. 115-128.

K. Budzyńska i in., 2014, The Polish School of Argumentation: A Manifesto, „Argumentation” vol. 28, nr 3, s. 267-282.

A. Budzyńska-Daca, 2005, Cnoty i retoryka $w$ dziele Sebastiana Petrycego z Pilzna, Katowice.

A. Budzyńska-Daca, 2012a, Format from the Rhetorical Perspective: Principles of the Polish Pre-electoral TV Debates in 1995-2010 [w:] M. Załęska (red.), Rhetoric and Politics: Central/Eastern European Perspectives, Cambridge, s. 264-282.

A. Budzyńska-Daca, 2012b, Idea debaty a reguły interakcji $w$ formatach polskich telewizyjnych debat przedwyborczych, "Studia Medioznawcze” nr 1, s. $45-59$. 
A. Budzyńska-Daca, 2013, Debata jako gatunek retoryczny, „Poradnik Językowy" z. 6, s. 19-34.

A. Budzyńska-Daca, 2015, Retoryka debaty. Polskie wielkie debaty przedwyborcze 1995-2010, Warszawa.

A. Budzyńska-Daca (red.), 2016, 20 lat polskich telewizyjnych debat przedwyborczych, Warszawa.

A. Budzyńska-Daca, A. Kampka, K. Molek-Kozakowska (red.), 2016, Retoryka wizerunku medialnego, Warszawa.

A. Budzyńska-Daca, J. Kwosek, 2009, Erystyka, czyli o sztuce prowadzenia sporów. Komentarze do Schopenhauera, Warszawa.

A. Budzyńska-Daca, E. Modrzejewska (red.), 2018, Retoryka negocjacji. Scenariusze, Warszawa.

K. Burke, 1945, A Grammar of Motives, Berkeley.

K. Burke, 1950, A Rhetoric of Motives, Berkeley.

M.K. Chalecki, 2009 [1589-1653], Kompendium retoryczne, red. J. Nowaszczuk, M. Skwara, Szczecin.

M. Choinski, 2016, The Rhetoric of the Revival: The Language of the Great Awakening Preachers. New Directions in Jonathan Edwards Studies (Book 1), Göttingen.

M. Choiński, 2020, Southern Hyperboles, Baton Rouge.

H. Cichocka, 1993, Zarys historii retoryki: od poczatku do upadku cesarstwa bizantyńskiego, Warszawa.

H. Cichocka, 1994, Teoria retoryki bizantyńskiej, Warszawa.

H. Cichocka, 2004, Mimesis i retoryka $w$ traktatach Dionizjusza z Halikarnasu a tradycja bizantyńska, Warszawa.

M. Ciszewska, 2016, Tuliusz domowy. Świeckie oratorstwo szlacheckie kregu rodzinnego (XVII-XVIII wiek), Warszawa.

R. Cieślak (red.), 2008, Retoryka ciała $w$ dyskursie publicznym, Toruń.

M. Czerenkiewicz, 2019, Polonia illustrata. Eacińska twórczość panegiryczna Szymona Starowolskiego, Warszawa.

M. Czyżewski, S. Kowalski, A. Piotrowski (red.), 1997, Rytualny chaos. Studium dyskursu politycznego, Kraków.

M. Czyżewski, S. Kowalski, T. Tabako, 2010, Retoryka i polityka. Dwudziestolecie polskiej transformacji, Warszawa.

T. Dobrzyńska, 1994, Mówiąc przenośnie. Studia o metaforze, Warszawa.

S. Dubisz, 1992, Jezyk i polityka: szkice $z$ historii stylu retorycznego, Warszawa.

S.K. Foss, 2017, Rhetorical Criticism: Exploration and Practice, Prospect Heights.

B. Gaj, 2003, Retoryka podstawowym narzędziem badań nad dawnym ślaskim oratorstwem. Cyceronianizm śląski [w:] J.Z. Lichański (red.), Uwieść słowem, czyli retoryka stosowana, Warszawa, s. 147-164.

B. Gaj, 2007, Tradycje retoryczne na dawnym Ślasku (XVI-XVIII wiek), Katowice-Opole.

M. Głowiński, 1991, Nowomowa po polsku, Warszawa.

M. Głowiński, 2009, Nowomowa i ciagi dalsze: Szkice dawne i nowe, Kraków.

M. Gondek, 2018, PRAXIS PHRONESIS RHETORICA. Filozoficzne podstawy aktów doradczych $w$ tradycji perypatetyckiej, Lublin.

P. Gondek, 2020, Subjective Basis for Elucidating Communication in the Personalistic Perspective, „Res Rhetorica” vol. 7, s. 72-85. 
A. Gorzkowski, 2004, Bene atque ornate: twórczość łacinska Jana Kochanowskiego w świetle lektury retorycznej, Kraków.

M. Hanczakowski, J. Niedźwiedź (red.), 2003, Retoryka a tekst literacki, t. 1-2, Kraków.

B. Hordecki, 2017, Wokót politycznego wymiaru zwiąków retoryki z logika [w:] B. Sobczak (red.), Powinowactwa retoryki, Poznan, s. 233-247.

B. Hordecki, 2018, The Strategic Dimension of the Eristic Dialectic in the Context of the General Theory of Confrontational Acts and Situations, „Przeglad Strategiczny" 11, s. 19-26.

M. Jabłonowski, T. Gackowski, 2012, Tożsamość nauk o mediach. Obszary, perspektywy, postulaty, „Studia Medioznawcze” 2(49), s. 15-24.

J. Jabłońska-Bonca, 2002, Prawnik a sztuka negocjacji i retoryki, Warszawa.

J. Jabłońska-Bonca, K. Zeidler, 2016, Prawnik a sztuka retoryki $i$ negocjacji, Warszawa.

A.D. Jaroszyńska, 1988, Krytyka retoryczna $w$ Stanach Zjednoczonych Ameryki. Zarys dziejów i najnowsze kierunki badawcze, „Pamiętnik Literacki” R. 79, z. 3, s. 97-119.

Cz. Jaroszyński, P. Jaroszyński, 1998, Podstawy retoryki klasycznej, Warszawa.

C.D. Johnson, 2010, Hyperboles: The rhetoric of excess in baroque literature and thought, Cambridge.

W. Jost, W. Olmsted (red.), 2012, Retoryka i krytyka retoryczna, red. nauk. wydania polskiego J.Z. Lichański, Warszawa.

I. Kamińska-Szmaj, 2001, Słowa na wolności: język polityki po 1989 roku: wypowiedzi, dowcip polityczny, słownik inwektyw, Wrocław.

I. Kamińska-Szmaj, 2007, Agresja językowa w życiu publicznym. Leksykon inwektyw politycznych 1918-2000, Wrocław.

A. Kampka, 2009, Perswazja w języku polityki, Warszawa.

A. Kampka, 2011, Retoryka wizualna. Perspektywy i pytania, „Forum Artis Rhetoricae" nr 1, s. 7-23.

A. Kampka (red.), 2012, Między znaczeniem a działaniem: retoryka i władza, Warszawa.

A. Kampka, 2013a, Rhetoric of the Crisis. Polish parliamentarian debates on the future if the EU [w:] G. Kišiček, I.Ž. Žagar (red.), What Do We Know About The World? Rhetorical and Argumentative Perspectives, Windsor, s. 178-203.

A. Kampka, 2013b, Retoryka wizualna w sporach, „Forum Artis Rhetoricae” vol. 3, nr 34, s. 61-85.

A. Kampka, 2014a, Debata publiczna. Zmiany społecznych norm komunikacji, Warszawa.

A. Kampka (red.), 2014b, Retoryka wizualna. Obraz jako narzędzie perswazji, Warszawa.

A. Kampka, K. Molek-Kozakowska (red.), 2016, Rhetoric, knowledge and the public sphere, Frankfurt am Main.

H. Karaś, E. Wierzbicka-Piotrowska, 2002, Język polski. Wśród znaków kultury. Retoryka. Podręcznik dla liceum ogólnokształcacego, liceum profilowanego i technikum, Kielce.

J. Kiereś-Łach, 2015, Filozofia i retoryka. Kontekst myślowy nowej retoryki Chaima Perelmana, Lublin.

R. Kleszcz, 2005, Teoria argumentacji, filozofia, logika. Uwagi o teorii Chaima Perelmana, „Forum Artis Rhetoricae” nr 3-4, s. 22-35. 
K. Kłosińska, 2003, Elementy retoryki romantycznej i retoryki liberalnej $w$ polskich tekstach politycznych po 1989 roku, „Biuletyn Polskiego Towarzystwa Językoznawczego" vol. 59, s. 125-138.

K. Kłosińska, 2005, O retoryce partii politycznych [w:] U. Jakubowska, K. Skarżyńska (red.), Demokracja w Polsce. Doświadczenie zmian, Warszawa, s. 210-221.

K. Kłosińska, 2012, Etyczny i pragmatyczny. Polskie dyskursy polityczne po 1989 roku, Warszawa.

M. Kochan, 2005, Pojedynek na słowa. Techniki erystyczne w publicznych sporach, Kraków.

M. Kochan, 2016, Retoryka biznesu: między wiarygodnościa a zrozumiałościa [w:] B. Kamińska, S. Milewski (red.), Logopedia artystyczna, Gdańsk, s. 419-436.

M. Korolko, 1990, Sztuka retoryki. Przewodnik encyklopedyczny, Warszawa.

M. Korolko, 2001, Retoryka i erystyka dla prawników, Warszawa.

M. Korolko, 2010, Podręcznik retoryki homiletycznej, Kraków.

R. Krzywy, 2014, Poezja staropolska wobec genologii retorycznej. Wprowadzenie do problematyki, Warszawa.

R. Kuś, 2016, Retoryka polityczna Richarda Nixona, Kraków.

R. Kuś, 2020, 'Our Grief and Anger': George W. Bush's Rhetoric in the Aftermath of 9/ 11 as Presidential Crisis Communication, „Res Rhetorica” 7(1), s. 44-60.

H. Lausberg, 2002, Retoryka literacka. Podstawy wiedzy o literaturze, Bydgoszcz.

P. Lewiński, 1999, Retoryka reklamy, Wrocław.

P. Lewiński, 2012, Neosofistyka. Argumentacja retoryczna w komunikacji potocznej, Wrocław.

J.Z. Lichański, 1991, Polskie badania nad retoryką. Stan i potrzeby, Warszawa.

J.Z. Lichański, 1992, Retoryka: od średniowiecza do baroku: teoria i praktyka, Warszawa.

J.Z. Lichański, 1998, Łukasz Górnicki Sarmacki Castiglione, Warszawa.

J.Z. Lichański, 2000, Retoryka: od renesansu do współczesności. Tradycja i innowacja, Warszawa.

J.Z. Lichański, 2003a, Retoryka w Polsce. Studia o historii, nauczaniu i teorii w czasach I Rzeczypospolitej, Warszawa.

J.Z. Lichański, 2003b, Uwieść słowem, czyli retoryka stosowana, Warszawa.

J.Z. Lichański, 2007, Retoryka: historia, teoria, praktyka, t. 1-2, Warszawa.

J.Z. Lichański, 2011, Krytyka retoryczna. Wprowadzenie do metody, „Zagadnienia Rodzajów Literackich" R. 54, z. 2(108), s. 267-301.

J.Z. Lichański, 2017, W poszukiwaniu najlepszych form komunikacji, czyli dlaczego wciaż jest nam potrzebna retoryka?, Kraków.

J.Z. Lichański, 2018, Badania retoryczne w Polsce (2001-2017): wprowadzenie do bibliografii, „Forum Artis Rhetoricae” nr 2(53), s. 7-73.

J.Z. Lichański, E. Lewandowska-Tarasiuk (red.), 2003, Nauczanie retoryki w teorii i praktyce, Warszawa.

A. Mamcarz-Plisiecki, 2018, Retoryka i językoznawstwo - obszary spotkania, „Roczniki Humanistyczne” LXVI (6), s. 111-135.

M. Marcjanik (red.), 2006, Retoryka codzienności, Warszawa.

W. Marciszewski, 1991, Logika z retorycznego punktu widzenia, Warszawa.

C. Mielczarski (red.), 2017, Retoryka klasyczna i retoryka współczesna. Pola i perspektywy badań, Warszawa. 
C. Mielczarski, 2011, Dziedzictwo klasycznej sofistyki i kultura współczesna, „Forum Artis Rhetoricae” nr 3, s. 7-25.

C. Mielczarski, 2017, Retoryka, prawda, polityka. Od starożytności do współczesności, Warszawa.

E. Modrzejewska, 2012, Retoryczna strategia sporu politycznego w perspektywie framingu na podstawie dzienników opinii z lat 2005-2009 [w:] A. Kampka (red.), Między znaczeniem a działaniem. Retoryka i władza, Warszawa, s. $153-170$.

E. Modrzejewska, 2013, Retoryczna strategia sporu a fotograficzne gatunki dziennikarskie - przykłady realizacji, „Studia Medioznawcze” vol. 3(54), s. 75-98.

E. Modrzejewska, 2014, Spór polityczny jako strategia retoryczna. Na podstawie materiału prasowego w okresie rząów Prawa i Sprawiedliwości 2005-2007 oraz Platformy Obywatelskiej 2007-2009, praca doktorska, Uniwersytet Warszawski.

E. Modrzejewska, 2019, O wartościach w zwizualizowanej informacji [w:] A. Budzyńska-Daca, E. Modrzejewska (red.), Retoryka $i$ wartości, Warszawa, s. $251-264$.

M. Mokrzan, 2010, Tropy, figury, perswazje. Retoryka a poznanie $w$ antropologii, Wrocław.

M. Mokrzan, 2019, Klasa, kapitał i coaching w dobie późnego kapitalizmu. Perswazja neoliberalnego urzadzania, Toruń.

K. Molek-Kozakowska, 2010a, Rhetorical styles in Internet-mediated political discourse concerning Polish gender parity debate 2009/2010, "Stylistyka" nr 19, s. 145-159.

K. Molek-Kozakowska, 2010b, The rhetoric of space in political discourse: Spatial metaphors in selected speeches of the European Commission [w:] A. Ciuk, K. Molek-Kozakowska (red.), Exploring Space: Spatial Notions in Cultural, Literary and Language Studies, vol. 2: Space in Language Studies, Newcastle, s. 93-103.

K. Molek-Kozakowska, 2011, Territorialization in political discourse: A pragma-linguistic study of Jerzy Buzek's inaugural speeches [w:] M. Pawlak, J. Bielak (red.), New Perspectives in Language, Discourse and Translation Studies, Berlin, s. 177-188.

K. Mosiołek-Kłosińska, T. Zgółka (red.), 2003, Język perswazji publicznej, Poznań.

B. Niebelska-Rajca, 2012, „Enargeia” $i$ „energeia” $w$ teoriach literackich renesansu i baroku, Warszawa.

K. Obremski, 2004, Retoryka dla studentów historii, politologii i dziennikarstwa, Toruń.

B. Otwinowska, 1990, Retoryka [w:] Słownik literatury staropolskiej, WrocławWarszawa-Kraków.

K. Ożóg, 2004, Język w służbie polityki. Językowy kształt kampanii wyborczych, Rzeszów.

J. Partyka, 2012, Władza nad sumieniami: retoryka penitencjałów i poradników dla spowiedników [w:] A. Kampka (red.), Retoryka i władza. Między znaczeniem a działaniem, Warszawa, s. 125-133.

J. Partyka, 2014, „Una Matrona in habito honesto”, czyli perswazja zwizualizowana [w:] A. Kampka (red.), Retoryka wizualna. Obraz jako narzędzie perswazji, Warszawa, s. 57-67. 
J. Partyka (red.), 2017, Normy komunikacji: między retoryka a językiem, seria Pro Rhetorica, Warszawa.

E. Pawlak-Hejno, 2016, Bojownice czy wariatki? Obraz sufrażystek angielskich w prasie polskiej (1911-1914), Lublin.

W. Pisarek, 2002, Nowa retoryka dziennikarska, Kraków.

W. Pisarek, 2007, O mediach i języku, Kraków.

R. Przybylska, W. Przyczyna (red.), 2001, Retoryka dziś - teoria i praktyka, Kraków.

M. Rusinek, 2003, Między retoryka a retorycznościa, Kraków.

M. Rusinek, 2012, Retoryka obrazu. Przyczynek do percepcyjnej teorii figury, Gdańsk.

M. Rusinek, K. Kłosińska, 2019, Dobra zmiana. Czyli jak się rządzi światem za pomoca słów, Kraków.

M. Rusinek, A. Załazińska, 2005, Retoryka podręczna. Czyli jak wnikliwie słuchać i przekonująco mówić, Kraków.

M. Rusinek, A. Załazińska, 2010, Retoryka dnia codziennego. Poradnik nie tylko językowy, Warszawa.

M. Rusinek, A. Załazińska, 2013, Co Ty mówisz? Magia słów, czyli retoryka dla dzieci, Kraków.

P. Rybiński, K. Zeidler, 2010, Leksykon retoryki prawniczej. 100 podstawowych pojęć, Warszawa.

W. Ryczek, 2016, Antystrofa dialektyki. Teoria retoryczna Bartłomieja Keckermanna, Torun.

M. Ryszkiewicz, 2021, Retoryka polskiej powieści kryminalnej po roku 1989. Preliminaria, Lublin.

M. Rzepecka, 2018a, Analyzing President Obama's Crisis Rhetoric: The Case of Syria, „Tekst i dyskurs - text und diskurs” 11, s. 405-25.

M. Rzepecka, 2018b, Richard Nixon's Cold War Rhetoric, Rzeszów.

M. Rzepecka, 2019, The Rhetorical Construction of the American Intervention in Libya: A Pentadic Analysis of President Barack Obama's Address to the Nation on March 28, 2011, „Polish Journal for American Studies” 13, s. 73-82.

L. Rzymowska, 2013, U źródeł pojmowania retoryki, Wrocław.

P. Sarna, M. Sęk-Iwanek (red.), 2016, Dyskursy widzialności. Słowa a obrazy, Katowice.

M. Skwara (red.), 2008, Retoryka. Tematy teoretycznoliterackie. Archiwum przekładów „Pamiętnika Literackiego” vol. 8, Gdańsk.

M. Skwara, 2010, Polskie drukowane oracje pogrzebowe XVII wieku, Gdańsk.

M. Smoleń-Wawrzusiszyn, 2018, Polskie dyskursy marketingu. Perspektywa lingwistyczna, Lublin.

B. Sobczak (red.), 2017, Powinowactwa retoryki, Poznań.

B. Sobczak, 2018, Retoryka telewizji, Poznań.

B. Sobczak, H. Zgółkowa (red.), 2007, Perspektywy polskiej retoryki, Poznań.

B. Sobczak, H. Zgółkowa (red.), 2009, Retoryka i etyka, Poznań.

B. Sobczak, H. Zgółkowa (red.), 2011, Dydaktyka retoryki, Poznań.

P. Stalmaszczyk, P. Cap (red.), 2014, Pragmatyka, Retoryka, Argumentacja. Obrazy języka i dyskursu w naukach humanistycznych, Kraków.

W. Suchoń, 2001, Prolegomena do retoryki logicznej, Kraków.

A. Szurek, 2015, Ujawnić, upamiętnić, zrozumieć - zapomnieć? Narracje o bombardowaniu Grodziska Mazowieckiego w styczniu 1945 roku - próba analizy 
retorycznej [w:] A. Gemra (red.), Literatura i kultura popularna. Badania, analizy, interpretacje, Wrocław, s. 138-153.

A. Szurek, 2019, Odra w Pruszkowie $i w$ fantazjach użytkowników lokalnych grup w mediach społecznościowych. Analiza metoda motywu fantazjowania, „Res Rhetorica” 6(3), s. 2-18.

K. Szymanek, 2001, Sztuka argumentacji. Słownik terminologiczny, Warszawa.

K. Szymanek, 2008, Argument z podobieństwa, Katowice.

K. Szymanek, K. Wieczorek, A. Wójcik, 2003, Sztuka argumentacji. Ćwiczenia $w$ badaniu argumentów, Warszawa.

O. Tarasewicz-Gryt, 2012, Attack as a Self-presentation Strategy: The Rhetoric of Law and Justice Party [w:] M. Załęska (red.), Rhetoric and Politics: Central/ Eastern European Perspectives, Cambridge, s. 227-243.

M. Tokarz, 2006, Argumentacja, perswazja, manipulacja, Gdańsk.

M. Trebska, 2014, Staropolskie mowy winszujace narodzin potomka. Rekonesans, „Res Rhetorica” nr. 1, s. 45-60.

R.E. Volkmann, 1995, Wprowadzenie do Retoryki Greków i Rzymian, tłum. L. Bobiatyński, red. wydania polskiego H. Cichocka, J.Z. Lichański, Warszawa.

J. Warchala, 2019, Formy perswazji, Katowice.

J. Wasilewski, 2006, Retoryka dominacji, Warszawa.

J. Wasilewski, 2012, Opowieści o Polsce. Retoryka narracji, Warszawa.

J. Wasilewski, A. Nita (red.), 2012, Instrukcja obsługi tekstów. Metody retoryki, Gdańsk.

H. White, 1978, Topics of Discourse. Essays in Cultural Criticism, Baltimore.

K. Wieczorek, 2013, Argumenty równi pochyłej. Analiza z perspektywy logiki nieformalnej, Katowice.

M. Wolny-Peirs, 2005, Język sukcesu we współczesnej polskiej komunikacji publicznej, Warszawa.

M. Worsowicz, 2013, O „duchu stosowności”. Teoria retoryczna a współczesna praktyka medialna, Łódź.

M. Załęska, 2005, Argumentacja $z$ perspektywy lingwistyki $i$ retoryki, „Forum Artis Rhetoricae" 3-4, s. 49-62.

M. Załęska, 2006, Pogranicza dyscyplin: językoznawstwo a retoryka [w:] M. Skwara (red.), Retoryka $w$ Polsce. Teoria i praktyka $w$ ostatnim pótwieczu, Szczecin, s. 11-38.

M. Załęska, 2008, Retoryka a językoznawstwo [w:] M. Barłowska, A. Budzyńska-Daca, P. Wilczek (red.), Retoryka, Warszawa, s. 174-194.

M. Załęska (red.) 2012a, Rhetoric and Politics: Central/Eastern European Perspectives, Cambridge.

M. Załęska, 2012b, Terminologia retoryki [w:] D. Brzozowska, W. Chłopicki (red.), Termin w językoznawstwie, Kraków, s. 111-124.

M. Załęska, 2013, Retoryka, wiedza, społeczeństwo: działalność Polskiego Towarzystwa Retorycznego [w:] Z. Kruszewski (red.), Towarzystwa naukowe $w$ Polsce-dziedzictwo, kultura, nauka, trwanie, t. 2, Warszawa, s. 292-306.

M. Załęska, 2014, Retorica della linguistica. Scienza, struttura, scrittura, Frankfurt am Main.

M. Załęska (red.), 2015, Retoryka w komunikacji specjalistycznej, Warszawa.

M. Załęska, 2016, Retoryczne aspekty popularyzacji naukowej, „Acta Universitatis Lodziensis. Folia Litteraria Polonica” nr 1(31), s. 59-70. 
M. Załęska, 2021, Rhetoric and linguistics: forms of connection in the interdisciplinary research, „Res Rhetorica” nr 8(3), s. 125-139.

M. Załęska, U. Okulska (red.), 2016, Rhetoric, discourse and knowledge, Frankfurt am Main.

H. Zgółka, T. Zgółka, 2001, Mówię więc jestem. Podręcznik języka polskiego dla licealistów od klasy pierwszej do matury, Kraków.

J. Ziomek, 2000, Retoryka opisowa, Wrocław.

\section{Rhetoric in Poland after 1989. An overview of research directions}

\section{Summary}

This paper is dedicated to the development of rhetoric in Poland after 1989 taking into account adaptation processes at two levels: communication practices and research reflection. The sociopolitical transformations have enabled an unrestricted development of rhetorical activities, which were impracticable in the former Eastern Bloc countries: advertising and marketing, political debates, civic engagement, academic freedom. The adaptation has taken place at the level of communication habits of citizens and rhetorical practices of rhetoric researchers themselves. The study adopts the descriptive methodology and focuses on several aspects: the process of internal differentiation of rhetorical studies, the influence of the American rhetorical criticism on the studies, the rhetorical perspective in linguistic research, media studies, and politics. The paper emphasises the cultural characteristics of Polish rhetorical studies, which draw inspiration from three main sources: 1) Old Polish oratory and its modern analyses from the perspective of literary studies; 2) analyses of the propaganda of the times of the Polish People's Republic, including the media; 3) modern concepts from the areas of argumentation, rhetorical criticism, discourse analysis, and media studies. The overview shows that, after 1989, rhetorical studies can be described as a self-organising system created by dense intertextual relations, relationship networks, and institutional frameworks rather than as a compilation of sparse individual works.

Keywords: rhetoric in Poland - language of politics - rhetorical criticism rhetoric and media - teaching of rhetoric - Polish Rhetoric Society

Trans. Monika Czarnecka 